\title{
Tingkat Adiksi Game Online Siswa SMPN 13 Padang
}

\author{
Nia Fitri Yanti ${ }^{1}$, Marjohan ${ }^{2}$, Rika Sarfika ${ }^{3}$ \\ ${ }^{1}$ Mahasiswa Program Studi Magister Keperawatan Universitas Andalas Padang \\ 2Dosen Universitas Negeri Padang \\ ${ }^{3}$ Dosen Universitas Andalas, Padang \\ Correspondence email: nivia_putri2@yahoo.com
}

\begin{abstract}
Abstrak. Angka kejadian adiksi game online pada remaja di Indonesia meningkat setiap tahunnya. Hal ini dapat menimbulkan dampak perilaku remaja. Penelitian ini bertujuan untuk mengetahui tingkat adiksi game online pada remaja di SMPN 13 Padang. Desain penelitian ini menggunakan analisis deskriptif. Responden dalam penelitian ini adalah siswa SMP N 13 Padang dengan jumlah 88 remaja yang memiliki pengalaman online games, dengan menggunakan teknik pengambilan sampel acak berstrata. Instrumen penelitian yang digunakan adalah GASA (skala penilaian kecanduan game). Hasil penelitian menunjukkan bahwa ratarata skor adiksi game online adalah 63, 32 di tingkat adiksi sedang. Ini berarti bahwa remaja SMPN 13 Padang perlu diberi intervensi untuk mengurangi tingkat adiksi mereka dan untuk mencegah efek negatif lebih lanjut untuk kehidupan produktif mereka. Disarankan bahwa perawat jiwa dapat berkolaborasi dengan pihak sekolah dan dinas pendidikan untuk melakukan terapi perilaku kognitif secara berkelanjutan dalam upaya untuk mencegah adiksi game online.
\end{abstract}

Kata kunci: Game Online; Adiksi; Remaja

Abstract. The incidence of online game addiction in teenagers of Indonesia is increasing every year. This lead to the impact of teenager's behavior. This study aims to determine online game addiction level of teenagers in SMPN 13 Padang. The design of this study uses the descriptive analyst. The sample in this study is the students of SMP N 13 Padang with the number of respondent who had online games experience is 88 teenagers by using stratified random sampling. The research instrument used is GASA (Game Addiction Scale Assessment). The results showed that the average online game addiction average score was 63,32 in intermediate level of addiction. This means that the teenagers of SMPN 13 Padang need to be given an intervention to decrease their addiction level and prevent further negative effect for their productive life. It is suggested that mental nurses can collaborate with the school and the education office to conduct cognitive behavior therapy on an ongoing basis in an effort to prevent online game addiction.

Keywords: Online Games; Addiction; Teenagers

\section{PENDAHULUAN}

Masa remaja merupakan salah satu periode peralihan perkembangan manusia, dimana seseorang belum dikatakan dewasa namun bukan lagi anak - anak (Stuart, 2016). Menurut World Health Organization (2016), diperkirakan kelompok remaja berjumlah 1.2 milyar atau $18 \%$ dari jumlah penduduk dunia. Penduduk Indonesia pada tahun 2017 pada semua usia berjumlah 258.704.986 orang, dari data tersebut remaja usia 10-14 tahun berkisar $8.73 \%$, usia $15-19$ tahun berkisar $8.57 \%$ remaja (Kemenkes, 2017).

Perkembangan identitas pada tahap remaja bagian yang terpenting karena remaja mengenal siapa dirinya, apabila remaja kehilangan identitas diri pada remaja mengakibatkan remaja bingung dalam menentukan dan menilai dirinya dalam bersikap sehingga remaja mudah terpengaruh dengan lingkungan, apalagi remaja yang sering merasa terbebani dengan beberapa masalah diantaranya, dari tuntutan akademik dan juga tanggung jawab sosial (Hurlock, 2009).

Kondisi tersebut membuat remaja mudah mengalami goncangan emosional dalam arti kondisi emosi yang negatif sehingga menimbulkan pola pikir yang mengganggu ketika menghadapi tugas yang sulit, ketidakyakinan remaja atas kemampuan akademik juga rendahnya kemampuan remaja dalam membentuk dan mempertahankan suatu relasi dengan orang lain membuat remaja tidak memiliki benteng yang kokoh untuk menghindari perilaku adiksi game online (Pratiwi et al., 2010).
Berdasarkan data survey pertumbuhan pasar game online di Indonesia tahun 2011 mengalami peningkatan jumlah pengguna yang mencapai angka 6,5 juta atau naik 500 ribu orang dari tahun 2010 yang hanya mencapai angka sekitar enam juta orang (Republika, 2011).

Tahun 2016 di Indonesia aktivitas remaja bermain game atau mengunduh video game berkisar $44,10 \%$ dan pada remaja berusia $10-24$ tahun terjadi berkisar 18,40\% (APJII, 2016). Prevalensi kejadian adiksi game online pada remaja Indonesia terus meningkat sehingga Indonesia di dunia urutan ke 6 dengan persentase 112,6\% pada tahun 2017 sehingga kondisi ini dapat menimbulkan dampak pada seseorang.

Berdasarkan di data yang didapatkan dari Satpol PP 2017 terkait penjaringan pada anak sekolah yang bermain game online pada jam sekolah SMP 13 merupakan siswa terbanyak yang terjaring berkisar 10 siswa dari 55 siswa yang berada pada 91 SMP sekota padang baik SMP negeri maupun SMP swasta.

Hasil wawancara yang dilakukan kepada 10 siswa mengatakan bahwa seluruh siswa senang bermain game online dan sering bermain game online. Bermain game onlineyang dirasakan siswa bisa untuk mengurangi stress serta permainan yang ada sangat menarik yang membuat siswa ketagihan, didapatkan 8 orang $(80 \%)$ siswa kalau sudah bermain game online akan sulit untuk berhenti dan 2 orang (20\%) siswa mengatakan masih bisa membagi waktu belajar dengan bermain game online. 


\section{METODE PENELITIAN}

Penelitian ini merupakan penelitian kuantitatif dengan menggunakan pendekatan analisis deskriptif untuk mengetahui tingkat adiksi game online siswa SMPN 13 Padang pada tahun ajaran 2018-2019. Penelitian dilakukan bulan Oktober 2018. Jumlah sampel dalam penelitian ini sebanyak 88 orang siswa SMPN 13 Padang yang sudah termasuk kategori adiksi game online berdasarkan hasil screening DSM $V$ yang sudah dilakukan sebelumnya. Teknik penelitian sampling dengan menggunakan stratified random sampling. Data dianalisis univariat untuk diikutsertakan dalam analisis deskriptif menggunakan sentral tendency karena data terdistribusi normal dengan $p=0.2(p>0,05)$.

\section{HASIL DAN PEMBAHASAN \\ Karakteristik responden}

Karakteristik responden dapat dilihat pada tabel di bawah ini:

Tabel 1. Karakteristik Responden Tingkat Adiksi Game Online Pada Siswa SMPN 13 Padang $(\mathrm{N}=88)$

\begin{tabular}{llcc}
\hline \multicolumn{2}{c}{ Karakteristik Responden } & $\boldsymbol{f}$ & $\%$ \\
\hline Usia & 12 tahun & 26 & 29,5 \\
Responden & 13 tahun & 27 & 30,7 \\
& 14 tahun & 27 & 30,7 \\
\multirow{4}{*}{ Kelas } & 15 tahun & 8 & 9,1 \\
& Kelas 1 & 32 & 36,4 \\
& Kelas 2 & 30 & 34,1 \\
Jenis & Kelas 3 & 26 & 29,5 \\
Kelamin & Siswa Laki-Laki & 62 & 70,5 \\
Lama & Siswa Perempuan & 26 & 29,5 \\
Bermain & 1 1 jam & 11 & 12,5 \\
& 2 jam - 2 jam & 44 & 50 \\
& & 26 & 29,5
\end{tabular}

\begin{tabular}{llcc} 
& 4 jam -6 jam & 6 & 6,8 \\
Jumlah & 5 jam & 1 & 1,1 \\
Hari & 1 hari & 5 & 5,7 \\
& $2-3$ hari & 30 & 34,1 \\
& $4-5$ hari & 33 & 37,5 \\
Alasan & $6-7$ hari & 20 & 22,7 \\
Bermain & Mencari Teman & 15 & 17 \\
& Menghilangkan Stress & 68 & 77,3 \\
& Bagian Komunitas & 4 & 4,5 \\
Tempat & Menjadi Orang Lain & 1 & 1,1 \\
Bermain & Rumah & 70 & 79,5 \\
& Warnet & 8 & 9,1 \\
Fasilitas & Dimana Saja & 10 & 11,4 \\
Bermain & Komputer & 12 & 13,6 \\
& Laptop & 1 & 1,1 \\
& Handphone & 65 & 73,9 \\
& Lain-Lain & 10 & 11,4 \\
\hline
\end{tabular}

Tabel 1. dapat dilihat bahwa sebagian besar siswa berusia 13 dan 14 tahun $(30,7 \%)$ dan paling banyak $(36,4 \%)$ duduk di bangku kelas 1 . Sebagian besar responden $(70,5 \%)$ berjenis kelamin laki-laki dan memiliki durasi bermain game paling banyak (50\%) bermain selama 1 sampai 2 jam. Kebanyakan siswa $(37,5 \%)$ bermain game 4 sampai 5 hari dalam seminggu. Lebih dari sebagian $(77,3 \%)$ siswa mengatakan alasan bermain game untuk menghilangkan stress dan paling banyak $(79,5 \%)$ siswa bermain game di rumah dengan fasilitas yang digunakan terbanyak $(73,9 \%)$ adalah handphone.

\section{Tingkat Adiksi Game Online Siswa SMPN 13 Kota Padang}

Berikut ini hasil univariat tingkat adiksi game online pada siswa SMPN 13 Kota Padang Tahun 2018 dengan responden sebanyak 88 remaja:

Tabel 2. Tingkat Adiksi Game Online Siswa SMPN 13 Kota Padang

\begin{tabular}{ccccccc}
\hline Skor Adiksi & Mean & Median & SD & Min-Max & $\mathbf{9 5 \%}$ Cl & P value \\
\hline Skor adiksi game online & 63,32 & 63 & 11,16 & $44-105$ & $60,95-65,98$ & 0,200 \\
\hline
\end{tabular}

Tabel 2. menunjukkan bahwa rerata skor tingkat adiksi game online pada siswa SMPN 13 Padang adalah 63,32. Artinya, rerata tingkatan adiksi remaja di SMPN 13 Padang termasuk kategori sedang.

\section{Pembahasan}

Bagi sebagian besar remaja, permainan adalah salah satu aktifitas yang menyenangkan (Kuss \& Griffiths, 2012). Alternatif hiburan yang dipilih remaja salah satunya adalah game online. Remaja akan memainkan game online untuk menghibur dan menjadikan ini sebagai sarana alternatif pengalihan dari kesibukannya (Ulfa, 2017). Sesuai dengan penelitian yang telah dilakukan di SMPN 13 Padang, remaja memilih game online sebagai salah satu sarana hiburannya.

Sementara itu dari hasil penelitian diperoleh bahwa sebagian besar dari penelitian ini respondennya laki-laki. Sesuai dengan penelitian yang telah dilakukan oleh Paaben, Morgenroth \& Stratemeyer (2017), bahwasanya mayoritas pemain game online adalah lakilaki. Ini terjadi karena game online menggunakan aplikasi atau software yang rumit untuk dipakai. Sehingga perempuan malas untuk bermain. Perempuan lebih cenderung menggunakan hal yang simpel, namun tidak ditemukan pada game online. Sedangkan sebaliknya terjadi pada laki-laki. Laki-laki jika menyukai sebuah permainan, maka dia tidak memikirkan persoalan aplikasi atau software yang rumit.

Berdasarkan hasil penelitian pada siswa SMPN 13 Kota Padang didapatkan bahwa responden memiliki durasi bermain game paling banyak $(50 \%)$ bermain selama 1 sampai 2 jam. Kebanyakan siswa (37,5\%) bermain game 4 sampai 5 hari dalam seminggu. Sama seperti beberapa penelitian sebelumnya yang didapatkan bahwa siswa bermain game online selama 1 sampai 2 jam karena itu merupakan waktu yang sesuai dengan kepuasan bermainnya dan memainkan game selama 4-5 hari dalam seminggu. Jika kurang dari waktu itu,maka kepuasannya akan berkurang (Ulfa, 2017).

Adiksi game online merupakan sebuah perilaku kecanduan yang berlebihan terhadap game online. Kecanduan tersebut merupakan perasaan yang sangat kuat sehingga ingin lagi dan lagi dalam melakukan sesuatu, dalam hal ini lebih kepada kecanduan terhadap game online (Ulfa, 2017). Kecanduan bermain game online dapat terlihat dari intensitas lama bermain. Seseorang yang sudah kecanduan game online akan 
terus bermain dengan intensitas yang sering (Vollmer, Randler, Horzum, \& Ayas, 2014).

Berdasarkan penelitian yang dilakukan pada siswa di SMPN 13 Padang didapatkan barwa tingkat adiksi game online dengan kategori paling tinggi berada pada tingkat adiksi sedang, yaitu sebanyak 60 orang (68,15\%). Tingkat adiksi tinggi sebanyak 15 orang $(11,4 \%)$ dan hanya 13 orang $(14,75 \%)$ yang berada pada tingkat adiksi rendah. Hal ini berarti sebelum diberikan terapi CBT terhadap siswa SMPN 13 Padang, tingkat adiksi bermain game online berada paling banyak pada tingkat sedang.

Menurut Dong \& Potenza (2015), adiksi game online tingkat sedang membutuhkan terapi perilaku tanpa perlu terapi farmakologis untuk mengurangi pengaruh negatif kecanduan bermain pada remaja serta mencegah peningkatan tingkat adiksi menjadi lebih tinggi. Untuk itulah diperlukan pemberian intervensi secara terus menerus sehingga dapat menimbulkan perubahan kepada responden. Hal ini diharapkan terapi perilaku kognitif dapat mengubah perilaku dan pikiran negatif responden menjadi positif atau setidaknya jadi lebih baik, seperti kemampuan remaja untuk menyadari game online dapat menjadikan mereka menjadi malas belajar, pola makan terganggu dan malas beribadah .

Menurut Sunarto \& Hartono (2002) dalam (Santoso \& Purnomo, 2017), faktor internal dapat menyebabkan adiksi game online sehingga terjadi perubahan keterampilan sosial remaja adalah kondisi jasmani yang kurang baik, proses belajar yang terganggu, pengalaman tidak menyenangkan dan ketidakmampuan mengatasi konflik diri dan lingkungan. Sedangkan faktor eksternal, yaitu pola asuh keluarga yag kurang tepat, pengaruh lingkungan sekitar atau lingkungan sekolah tidak sehat, pengaruh budaya dan agama yang tidak selaras dengan kehendak remaja.

Dari analisa kuesioner penelitian ini ditemukan alasan utama remaja bermain game untuk menghilangkan stres. Xu, Turel, \& Yuan (2012), mengatakan bahwasanya game online dapat menghilangkan stres baik untuk pelajar, atau pun pekerja. Game dapat merefresh otak sehingga setelah bermain game, kebosanan dan kejenuhan dapat berkurang dan seseorang dapat melanjutkan pekerjaan sebelumnya. Bermain game online dapat memperbaiki koping yang maladaptif menjadi adaptif (Vasiliu \& Vasile, 2017).

Menurut Ulfa (2017), motivasi bermain game online salah satunya adalah menghilangkan stres. Hal ini merupakan alasan terbanyak seseorang termotivasi bermain game online dari sekian banyak alasan lainnya. Namun dengan persepsi bahwa bermain game online akan meningkatkan rasa gembira dan menurunkan stres, hal ini juga berdampak buruk pada minat remaja dalam melakukan kegiatan lain seperti malas belajar, pola makan terganggu dan malas beribadah (Pirantika, 2017).

\section{SIMPULAN}

Rerata tingkat adiksi game online pada siswa SMPN 13 Padang berada pada tingkat adiksi sedang dengan rerata skor 63,32.

\section{Saran}

Pihak sekolah dapat menambahkan program tentang kesehatan jiwa pada kegiatan atau ekstrakurikuler siswa di PIKR (Program Pusat Informasi dan Konsultasi Remaja) untuk melakukan upaya promosi kesehatan jiwa dan bekerjasama dengan perawat jiwa untuk melakukan terapi CBT sebagai intervensi keperawatan yang diharapkan dapat mengubah perilaku negative bermain game online serta mengadakan pendidikan kesehatan tentang cara mengatasi adiksi game online.

\section{DAFTAR PUSTAKA}

APJII. (2016). Statistik Pengguna Internet Indonesia 2016. Jakarta: APJII.

Dong, G., \& Potenza, M. N. (2015). A cognitivebehavioral model of Internet gaming disorder: Theoretical underpinnings and clinical implications. J Psychiatr Res, 143(5), 951-959. https://doi.org/10.1017/S0950268814002131.Tube rculosis

Hartono, S. \& A. (2002). Perkembangan Peserta Didik. Jakarta: Rineka Cipta.

Hurlock, E. B. (2009). Psikologi Perkembangan. Jakarta: Erlangga.

Kemenkes, R. (2017). PROFIL KESEHATAN INDONESIA TAHUN 2017. Jakarta.

Kuss, D. J., \& Griffiths, M. D. (2012). Adolescent Online Gaming Addiction. Education and Health, 30(1), 15-17.

Paaben, B., Morgenroth, T., \& Stratemeyer, M. (2017). What is a True Gamer? The Male Gamer Stereotype and the Marginalization of Women in Video Game Culture. Sex Roles, 76(7-8), 421435. https://doi.org/10.1007/s11199-016-0678-y

Pirantika, A. (2017). Adiksi Bermain Game Online PAda Siswa Sekolah Dasar Negeri Bajing 1 Kecamatan Kroya Kabupaten Cilacap.

Pratiwi, P. C., Andayani, T. R., Karyanta, N. A., Studi, P., Fakultas, P., \& Maret, U. S. (2010). Perilaku Adiksi Game-online Ditinjau dari Efikasi Diri Akademik dan Keterampilan Sosial pada Remaja di Surakarta. Jurnal IImiah Psikologi Candrajiwa, 1(2), 1-15.

Republika. (2011, August 19). Game Indonesia Juara Asia Online Game Awards. Jakarta.

Santoso, Yohanes Rikky Dwi \& Purnomo, J. T. (2017). Hubungan Kecanduan Game Online Terhadap Penyesuaian Sosial Pada Remaja, 27-44.

Stuart, G. W. (2016). Prinsip dan Praktik Keperawatan Kesehatan Jiwa Stuart. Jakarta: Elsevier Ltd.

Ulfa, M. (2017). Pengaruh Kecanduan Game Online terhadap Perilaku Remaja di Mabes Game Center jalan Hr. Subrantas Kecamatan Tampan Pekanbaru. Jom. FISIP, 4(1), 1-13.

Vasiliu, O., \& Vasile, D. (2017). Cognitive-Behavioral Therapy for Internet Gaming Disorder and Alcohol Use Disorder-A Case Report. International Journal of Psychiatry and Psychotherapy, 2, 34-38. 
Vollmer, C., Randler, C., Horzum, M. B., \& Ayas, T. (2014). Computer game addiction in adolescents and its relationship to chronotype and personality. SAGEPUb, https://doi.org/10.1177/2158244013518054

World Health Organization. (2016). Mental Health. Quality of Suicide Mortality Data.

Xu, Z., Turel, O., \& Yuan, Y. (2012). Online Game Addiction Among Adolescents: Motivation and Prevention Factors. European Journal of Information Systems, 21(3), 321-340. https://doi.org/10.1057/ejis.2011.56 